\title{
E-MAIL WRITING: Providing Background Information in the Core of Computer Assisted Instruction
}

\author{
MA of TEFL, Behzad NAZARI \\ Islamic Azad University, \\ South Tehran Branch, Tehran, IRAN \\ MA of TEFL, Sahar NIKNEJAD \\ Islamic Azad University, \\ South Tehran Branch, Tehran, IRAN
}

\begin{abstract}
The present study highly supported the effective role of providing background information via email by the teacher to write e-mail by the students in learners' writing ability. A total number of $\mathbf{5 0}$ EFL advanced male students aged between 25 and $\mathbf{4 0}$ at different branches of Iran Language Institute in Tehran, Tehran.
\end{abstract}

Through the placement test of Oxford English Language Placement Test (OELPT) the students' proficiency level seems to be nearly the same. Participants were randomly assign into two groups of experimental and control, each consisting of 25 students. After the administration of the proficiency test, all groups were assigned to write topic 1 as the pre-test. Next, the teacher involved the learners in the new instruction (treatment).

During writing topics 2, 3, 4, 5, 6, and 7 experimental group's background knowledge was activated through e-mail before writing and e-mailing topics while the control group received no background knowledge activation through e-mail. After the treatment was given to the experimental group, the students in both groups were required to write another composition about the last topic, topic 8. Again, in this phase, none of the groups received any background information.

The results indicated that providing background information via e-mail by the teacher to write email by the students significantly improved learners' writing ability.

Keywords: Computer-assisted language learning, Computer-mediated communication, Asynchronous computer-mediated communication, Synchronous computer-mediated communication, Writing, Background Information, Holistic Scoring 


\section{INTRODUCTION}

Education technologies were one of the newest areas in the world in the second half of the 20th century. In the late 1950s, in developed countries, computers which have arrived the academic life are still developing without any stop throughout the world.

Today, computers have become more powerful, quicker, easier to use, more convenient and cheaper, and they can process and save much more information, as well.

At the end of the 20th century, the computer-mediated communication and the Internet have reformed the use of computers for language learning. Computers are no longer a way for just information processing but also a tool for information processing along with communication. With the help of the Internet, language Learners can now interact with others or target language speakers all over the world. According to Dhaif (1989), computers can never substitute the 'live' teacher, specifically in language teaching, where the attention is on mutual interaction between people. It can just accept a role in teaching the second or foreign language as help to the teacher.

The abbreviation of CALL which stands for Computer Assisted Language Learning is a term used by teachers and students to refer to the use of computers as parts of a language course (Hardisty \& Windeatt: 1989). It is traditionally described as a means of 'presenting, reinforcing and testing' particular language items. Firstly, the learner is provided with a rule and some examples, and then answers a set of questions which test her/his knowledge of the rule and the computer provides proper feedback and determines a mark, which may be stored for later scrutiny for the teacher. Jones \& Fortescue (1987) present that the traditional description of CALL is inappropriate and they introduce the computer as adjustable classroom aid, which can be used by teachers and learners, within and out of class, in different ways and for various purposes. On the other hand, as any other teaching aid, using the computer needs to be connected to ordinary classroom task and CALL lessons, like the other lessons, need to be planned meticulously.

Keeping up to date with e-learning is a -moving plan on the Internet. Today, the activities such as reading daily e-learning newsletters, online magazines and attending e-learning conferences are offered. Interpersonal communication involves learners in real life communication with main partners.

E-partners can be detected on the Net by employing ordinary search engines. Unfortunately, emailing haphazardly between pals does not lead to beneficial learning, and, as a rule, is restricted to sharing personal information. Even with appropriate key partners, e-mailing can often be challenging in the case of time and reliability of the relationship.

Since the telephone, e-mail appears to be the most substantial, unique way for communication and increasing relationships (Suller, 1998). First, it is easy to use. Second, people consider it to be familiar and safe - it is like letter writing. Third, it is the most usual and powerful. Unlike face to face communication, e-mail interaction is asynchronous, i.e. does not take place in 'real time'.

A person has time to think, evaluate, and compose a message. Having the chance of thinking time can immune e-partners from unnecessary misunderstandings and discussions. However, aperson's 
proficiency to interact beneficially via e-mail is highly based on their writing skills (Suller, 1998). E-mail is a less voluntary form of interacting than speech.

In contrast to conversation - where words issue forth and fade fast - writing puts one's views in a more clear, constant, tangible, and objective format. Weak writing can lead to misunderstandings and probably challenges. Spelling, grammar, vocabulary, sentence structure and style affect the nature of the writing and demonstrate one's character.

From its advent up to now, CALL developed in line with the equipment prepared by computer technology. As mentioned by Jones (2001), the significance of computer technologies in foreign language learning and teaching has been founded by many people. Language teachers and administrators find out the movement towards CALL; moreover, students require computers via the facilities which make them prepared for language learning. Advanced technological facilities have been at the service of CALL to make the highest communicative learning situations for activities that promote listening, speaking, reading, and writing skills. With the help of networks' high transfer potentials, it has been probable to achieve authentic cultural resources and get foreign language learners together with native speakers of the related language (CALICO, 2001). All language centers accept that it is not possible to make progress without modern technology and computers in the developed world.

Based on the mentioned facts, the present researcher aims to perform a study in the case of the effect of e-mail writing on learners' writing development. In order to make good in the academic context, students require a wide range of linguistic skills that will aid them both develop their learning opportunities and illustrate proficiency of their learning. For learners whose native language is not English, such proficiency has been especially hard to achieve in the domain of writing. No wonder writing is often considered to be the fourth skill.

This is because of the fact that naturally writing is instructed as the final, fourth stage of the sequence of learning the four skills (i.e. listening, speaking, reading, and writing). Critically, it is the most difficult of these skills too. Surprisingly, this sequence remained sound in the process of human language development

Writing, the most difficult skill among the four skills in language learning, has received attention after listening, speaking, and reading. For a large number of students writing seems to deal with great problems and most of these difficulties come from inadequate preparation for the writing task. Many techniques have been suggested to function as the pre-writing activities in order to pave the way for the students to improve their writing skill.

Activating students' background knowledge stands in a unique position among these techniques. Direct education on background knowledge can result in an approach such as previewing, where students are provided introductory material before they read special texts. Such introductory material may cover background information such as explanations of difficult concepts, definitions of new vocabularies, and translations of foreign phrases.

Through providing students' background knowledge, teachers will be able to indirectly touch other facets of academic performance, specially writing. 


\section{CALL THEORETICAL FRAMEWORK}

CALL is still a young field and does not have a theoretical framework. SLA researchers and practitioners suffer from the problems which ring true in the domain of CALL. In fact, because of the relative youth of CALL they are even more severe. Due to a lack of theoretical framework it is hard for researchers to compare and study findings from CALL studies. In the other words, there is no widely accepted theoretical framework to provide direction for improvement and application of CALL materials for practitioners (McCarthy, 1999). Rare resources are turned, if not wasted, in the process.

Mei Lin Ho (2000) claimed that ICT cooperative project between two schools in Singapore and Birmingham found various writing tasks via the electronic exchange of information. In this study the students' confidence, awareness and understanding of their own and their correspondents' cultures were promoted. The study also scrutinizes the role and place of the foreign language teachers over a period of research time, and argues the implications for both the teachers and learners. Students demonstrated a positive attitude towards writing and proved to be more motivated. Analysis of the electronic messages displayed a level of perfection in students' cognitive development.

Learners learnt to work cooperatively and developed their interaction skills. Pedagogical implications of the study cover knowledge on who, why, how, and what. In other words, teachers require to know well the people who are engaged in the study, the special domains for research and follow-up that have to be practiced clearly with special goals, understand the clear-cut purpose of the study and how it will assist participants in specific areas, and, ultimately, to know a clear step-by-step process of fulfillment.

Suggestions and rationale for using e-mail in foreign language teaching are provided in (Gonglewski et. al., 2001). Educational benefits of e-mail are: encouraging equal opportunity participation, expanding topics beyond classroom-based themes, extending language learning time and place, promoting student-centered language learning, and providing authentic interaction and a context for real-world communication. Many ideas for using e-mail are proposed: group e-mail interaction, e-mail exchanges in the group,

The survey done at the University of Canberra on computer use showed that the number of regular users of computers was a little more than half of the 128 respondents spending time surfing the Internet or e-mailing (Jones, 1998). Based on another survey conducted by Jones (2001) at Urbon University in Thailand, $100 \%$ of 68 respondents used computers for e-mail and expressed a desire to develop computer skills in order to improve their English.

\section{Statement of the Problem}

CALL has had different impacts on the foreign language learning process. In their study titled "Language learning in cyberspace", for second language learners from universities, Donaldson \& Kötter (1999) conducted a real-time MOO (Multiuser Object Oriented) system. For five months the sample used this system one session a week for cooperative tasks. 
The researchers came to the fact that such CALL applications are appealing, help students learn more communicatively, and inspire students in language learning. Kartal (2002) also conceded that computer use in foreign language teaching is triggering for students since computers can personalize learning, and aid students to learn quicker and simpler than before.

A large number of researches have studied the impacts of e-mail writing on grammar by asynchronous computer-mediated corrective feedback, but a very limited number of such researches studied the role of e-mail on writing, and none of these studies can be traced in an Iranian context. Regrettably, in Iran like many other countries in the world, writing does not receive the due attention. Teachers tend to give more importance to the reading skill which the learners need for their continuing study and their future academic life. Being regarded a neglected skill; writing should be paid the appropriate attention it deserves.

For this reason, some vigorous studies should be done to provide learners, teachers and administrators with some sound vision to the process of writing, especially through e-mail.

\section{Purpose of the Study}

To come to a good way and method to teach writing skill many researches have been done and to some extent came to some positive findings. In this new age of communication, students tend to communicate internationally through the technologies and they should be provided and supported to express themselves in a broad way. Sending and receiving e-mails is a dominant way of communication for the students to get closer to what they desire.

In the light of the problem statement, the present study aimed to determine whether providing background information via e-mail by the teacher and writing e-mail by the students is effective in learners' writing ability.

\section{Significance of the Study}

Most of the researches regarding providing background Information have so far been concerned with classroom contexts and numerous studies have corroborated the effectiveness of it in these environments. However, the problem is that not much investigation has been devoted to providing learners with background Information through computer technologies.

Therefore, there is a need to further investigate the impact of providing background Information through technologies on language improvement. Thus, the present study investigated the impact of providing background Information via e-mail by the teacher and writing e-mail by the students, in EFL context in Iran.

\section{Research Question and Hypothesis}

Based on the above mentioned problem, the present research attempted to answer the following main question:

Does providing background Information via e-mail by the teacher and writing e-mail by the students have any effect on Iranian EFL male learners' writing ability? 
In order to answer the preceding question, the following null hypothesis was formulated. Providing background Information via e-mail by the teacher and writing e-mail by the students does not have any effect on Iranian EFL male learners' writing ability.

\section{METHOD}

\section{Participants}

In order to investigate the effect of providing background information via e-mail by the teacher and e-mail writing on Iranian EFL learners' writing ability, the present researcher examines Iranian advanced learners. To do so, a total number of 75 EFL advanced male learners whose ages ranged between 25 and $\mathbf{4 0}$ at different Branches of Iran Language Institute in Tehran, attended the study, but just $\mathbf{5 0}$ of those students whose proficiency levels seem to be nearly the same were chosen as the main participants through the placement test.

Participants were randomly assign into two groups of experimental and control, each consisting of 25 students (Table: 1).

Table: 1

Randomly assign participants

\begin{tabular}{|l|l|}
\hline Groups & \\
\hline Male Experimental & 25 \\
Male Control & 25 \\
\hline
\end{tabular}

\section{Instruments}

Four instruments were used in this study:

\section{Oxford English Language Placement Test}

To make sure that the participants are at the same level of proficiency, advanced level, the Oxford English Language Placement Test was administrated. OELPT is a 50- item placement test developed by Oxford University Language Centre. The answer sheets of the 75 students who took the test were gathered and scored by the researcher. Those participants who had 41-50 correct answers out of $\mathbf{5 0}$ items were accepted to participate in this study as advanced learners. The participants were further, randomly divided into two parallel groups of experimental and control groups of homogenous learners.

\section{Pre-Test and Post-Test based on TOEFL iBT Writing Topics}

The last section on the TOEFL iBT is Writing, for which you have a total of $\mathbf{5 0}$ minutes. This part measures your ability to communicate clearly in writing and compose well-organized essays using correct grammar, spelling, vocabulary, and sentence structure. 
The participants were given one topic and 30 minutes to write an essay of about 4-5 paragraphs, or 300-350 words.

Students in both groups were supposed to write eight topics (chosen among recent TOEFL writing section) in different phases of the study, the pre-test and the post-test. The scores of the first writing were later used as the pre-test scores. In the case of topic 1 and 8 , none of the groups received background information via e-mail; they were just given topics and asked to write.

Since this study lasts 8 sessions within 4 weeks the students were just given 8 topics, one topic for each session. Topic 1 considered as the pre-test for both groups, topics 2, 3, 4, 5, 6, and 7 as the treatment for experimental group, and topic 8 as the post-test for both groups. During writing topics 2, 3, 4, 5, 6, and 7 experimental group's background knowledge was activated through email while the control group received no background knowledge activation through e-mail.

\section{Cue Cards}

Students in experimental group were sent some cards via e-mail by the teacher relevant to the topics, which illustrated different pictures or key words on them. Looking on these cards, learners' background knowledge was being activated and triggered to elaborate their comments on the related topics while the students in control group were just introduced the same topics without cue cards in the classroom to write a paragraph for the next session. So, this was just considered as one of the ways of activating background knowledge.

\section{E-mail and Computer}

The students in experimental groups received e-mail, containing cue cards and some special outline of the topics, on the writing topics and they replied the e-mail by typing the topics in the Word Software attaching to their e-mail and sending them to the present researcher. Fortunately, in this new age of communication, all of the participants were well conversant with the technology of computer, e-mail, and internet and they all have computers and access to the internet, so the investigator faced no challenge in this important case.

\section{Procedure \\ This study was conducted in five separate phases:}

\section{Sampling (based on Oxford English Language Placement Test)}

To make sure that the participants were at the same level of proficiency, advanced level, the Oxford English Language Placement Test was administrated. Students who had OELPT scores of 41-50 were considered as the main participants. They were further, randomly divided into two experimental and control groups.

\section{Pre-Test Administration}

After the administration of the proficiency test, both groups were assigned to write topic 1 as the pre-test. The aim was to compare the changes, if any, on the part of the learners' writing development after the final phase i.e., the post test. In this phase none of the groups received background information by means of e-mail; they were just given topic 1 and were asked to write about it. 


\section{Treatment}

In this phase, the teacher involved the learners in the new instruction (treatment). Like on the TOEFL writing section, both groups were assigned to write one topic, and given 30 minutes to write an essay of about 4-5 paragraphs, or 300-350 words in the classroom out of topics 2, 3, 4, 5, 6, and 7 and these topics were considered as the treatment for experimental group. During writing topics 2, 3, 4, 5, 6, and 7 experimental group's background knowledge was activated through email before writing and e-mailing topics while the control group received no background knowledge activation through e-mail.

\section{Post-Test Administration}

In the fourth phase and after the treatment was given to the experimental group, the students in all groups were required to write another composition about the last topic. Again, in this phase, none of the groups received any background information by means of e-mail and they were just given the topic and asked to write about it.

\section{A Brief Training Session for Raters}

After all the compositions were written, they were given to three raters including the researcher to score them. Compositions were scored by three different scorers because the more readers per paper, the more reliable the scores. Jacob et al (1981, p.69) have mentioned that "for maximum reader reliability each composition should be read by at least three raters, independently". Following this guideline, three raters, including the researcher, read the papers to make sure that the evaluation was valid, i.e. inter-rater reliability. Therefore, the mean score of three scores (by the raters) for each student on each topic was calculated as the final score of that topic.

During this phase, the criteria for scoring was chosen: holistic method of scoring, because Heaton (1990) has observed that if compositions were scored by three or four impression markers or holistic scores, the total mark will be found to be far more reliable than if the marks were awarded by

one analytic marker. He has also stated that the holistic method is a useful method of marking a huge number of compositions.

In this research the researcher chose the scale from 0 to 30, based on TOEFL writing score. Subjectivity of the scoring is decreased by considering the mean of three scores' marks as the tester's mark.

\section{Design}

This study is a true experimental research and has the pretest-posttest equivalent-groups design. The participants were randomly divided into two groups. The control group $(\mathrm{N}=25)$ received conventional instruction; whereas, the experimental group $(\mathrm{N}=25)$ received necessary background information by means of e-mail as the instruction type of treatment. The major variable which the researcher hoped to manipulate in this study (independent variable) includes providing background information by means of e-mail and writing e-mail but learners' writing ability is the dependent variable that the researcher measures to determine the effect of treatment on it in EFL advanced learners. 
The study includes both a pilot study and a main study and uses sampling procedure, so the design can be labeled true experimental.

\section{RESULTS AND DISCUSSION}

This section provides the detailed statistical analyses performed in this study and it represents every step which was taken for analyzing the obtained data in order to test the hypothesis of the study based on the results:

Providing background Information via e-mail by the teacher and writing e-mail by the students does not have any effect on Iranian EFL male learners' writing ability.

The collected data were fed into the SPSS software to be analyzed considering the scales of measurement of the variable of this study. The data analysis was first followed to examine the reliability of the instrument, and Coronbach's alpha values are obtained to compare the pilot study and actual data reliably. Statistical procedure in this study included the descriptive analysis and referential statistics of the scores obtained on the 3 tests of OELPT , pre-test, and post-test. In the main procedure of data analysis, the descriptive statistics of the scores were calculated. Then a series of $t$-tests were run to compare the results obtained from both groups.

Analysis of Scores on Proficiency Test

Before administering the treatment of the study, all participants of main study $(n=75)$ took the proficiency test i.e., Oxford English Language Placement Test (OELPT) to have their language proficiency pretested. The purpose of proficiency test was to manifest the learner's homogeneity or to show whether the learners' knowledge of English was at the same level. Every one of the participants was assigned a number that was fixed until the end of study.

The descriptive statistics of proficiency test is shown in table. 2. Regarding this table the minimum and maximum of the scores were 31 and 50 respectively. The mean of scores was 41.31 and standard deviation was $\mathbf{5 . 1 2}$. The far distance between the minimum and maximum of scores indicates that the distribution of scores is not normal.

Table: 2

Descriptive Statistics of the Obtained Scores from OELPT

\begin{tabular}{|l|l|l|l|l|l|l|l|l|}
\hline & N & Range & Minimum & Maximum & Mean & $\begin{array}{l}\text { Std. } \\
\text { Deviation }\end{array}$ & \multicolumn{2}{|l|}{ Skewness } \\
\cline { 2 - 8 } & Statistic & Statistic & Statistic & Statistic & Statistic & Statistic & Statistic & $\begin{array}{l}\text { Std. } \\
\text { Error }\end{array}$ \\
\hline $\begin{array}{l}\text { OELPT } \\
\text { Scores } \\
\text { Valid N } \\
\text { (listwise) }\end{array}$ & 75 & 19.00 & 31.00 & 50.00 & 41.4521 & 5.12088 & -.213 & .281 \\
\hline
\end{tabular}

As it was mentioned, the participants with scores below 41 were excluded from the study. Thus, as demonstrated by table 3, twenty five of participants were excluded from the main analysis. 
Table: 3

Descriptive Statistics for Homogenized Scores

\begin{tabular}{|l|l|l|l|l|l|l|l|l|}
\hline & \multicolumn{1}{|c|}{$\mathrm{N}$} & Range & Minimum & Maximum & Mean & Std. Deviation & \multicolumn{2}{c|}{ Skewness } \\
\cline { 2 - 8 } & Statistic & Statistic & Statistic & Statistic & Statistic & Statistic & Statistic & $\begin{array}{l}\text { Std. } \\
\text { Error }\end{array}$ \\
\hline $\begin{array}{l}\text { OELPT } \\
\text { Scores } \\
\begin{array}{l}\text { Valid N } \\
\text { (listwise) }\end{array}\end{array}$ & 50 & 9.00 & 41.00 & 50.00 & 45.3750 & 2.60854 & .204 & .374 \\
\hline
\end{tabular}

In order to prove the normality of the selected scores of proficiency test, another statistical procedure, namely, one sample Kolmogorov-Smirnov test was administered. As table 4 shows the most extreme differences between the scores is not significant. The measured significance level was 0.32 and it was higher than the assumed level of significance (i.e., 0.05 ), so it can be concluded that there was no significant difference between the observed distribution of selected scores of proficiency test, and the scores are normally distributed.

Table: 4

One-Sample Kolmogorov-Smirnov Test

\begin{tabular}{|ll|c|}
\hline & & OPT Scores \\
\hline $\mathrm{N}$ & & 50 \\
Normal Parameters $^{\mathrm{a}}$ & Mean & 45.3750 \\
& Std. Deviation & 2.60854 \\
Most Extreme Differences & Absolute & .151 \\
& Positive & .151 \\
Kolmogorov-Smirnov Z & Negative & -.093 \\
Asymp. Sig. (2-tailed) & & .955 \\
a. Test distribution is Normal. & .322 \\
\end{tabular}

So, as the first evidence, it highly confirmed the homogeneity of participants' proficiency level.

\section{RESULTS OF THE TOPICS MEAN SCORES}

Comparing the mean scores, as illustrated in table 5, we certainly observed that the mean score for topic1 in experimental group was $\mathbf{1 7 . 4 0}$ and this was $\mathbf{1 7 . 6 4}$ in control group. So, as the second evidence, it highly confirmed the homogeneity of participants' proficiency level, in male participants. 
Table: 5

Group Statistics for Male Participants

\begin{tabular}{|ll|c|c|c|c|}
\hline & Groups & $\mathrm{N}$ & Mean & Std. Deviation & Std. Error Mean \\
\hline Topic1 & Male Experimental & 25 & 17.40 & 1.581 & .316 \\
& Male Control & 25 & 17.64 & 1.350 & .270 \\
\hline Topic 2 & Male Experimental & 25 & 23.56 & 1.446 & .289 \\
& Male Control & 25 & 17.32 & 1.749 & .350 \\
\hline Topic 3 & Male Experimental & 25 & 23.16 & 1.281 & .256 \\
& Male Control & 25 & 16.64 & 1.497 & .299 \\
\hline Topic 4 & Male Experimental & 25 & 23.80 & 1.443 & .289 \\
& Male Control & 25 & 17.32 & 1.626 & .325 \\
\hline Topic 5 & Male Experimental & 25 & 22.76 & 1.665 & .333 \\
& Male Control & 25 & 17.44 & 1.710 & .342 \\
\hline Topic 6 & Male Experimental & 25 & 23.5200 & 1.12250 & .22450 \\
& Male Control & 25 & 17.7200 & 1.59478 & .31896 \\
\hline Topic 7 & Male Experimental & 25 & 23.6400 & 1.28712 & .25742 \\
& Male Control & 25 & 17.0800 & 1.86905 & .37381 \\
\hline Topic 8 & Male Experimental & 25 & 20.5600 & 1.58325 & .31665 \\
PostTest & Male Control & 25 & 16.9200 & 1.52534 & .30507 \\
\hline
\end{tabular}

On the other hand, in the case of topics $2,3,4,5,6,7$, and 8 the mean scores of experimental group were noticeably bigger than that of control group (informatively shown in Graph 4.1.). Based on this easy comparison we could reject the researcher's null hypothesis (Providing background Information via e-mail by the teacher and writing e-mail by the students does not have any effect on Iranian EFL male learners' writing ability) in that providing background Information via e-mail by the teacher and writing e-mail by the students affects and promotes Iranian EFL male learners' writing ability, but as far as we were going to elaborate on the data analysis of independent samples test of experimental and control groups we preferred to be more patient In rejecting the first null hypothesis. 


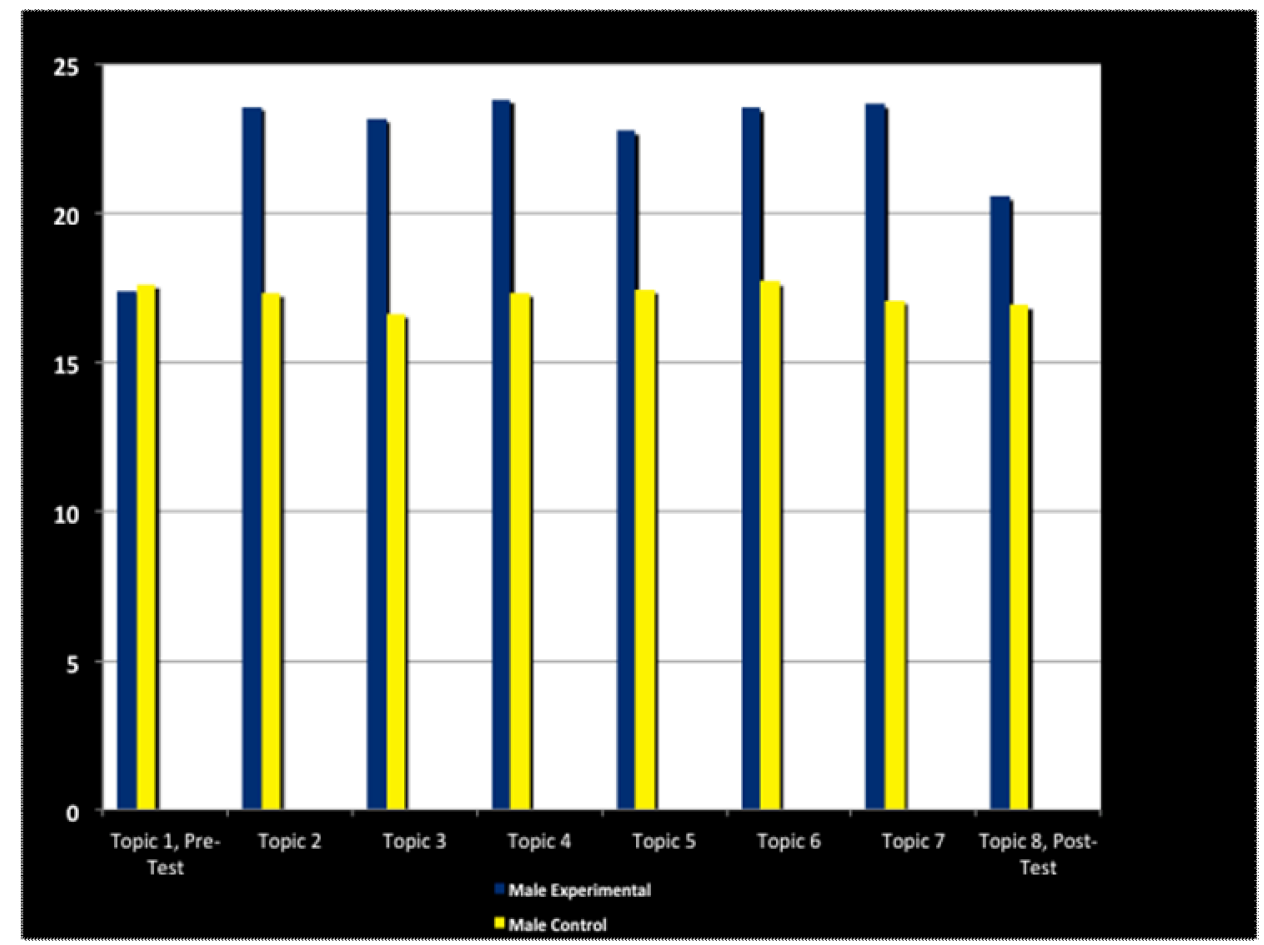

Graph: 1

Topics Mean Scores of Groups

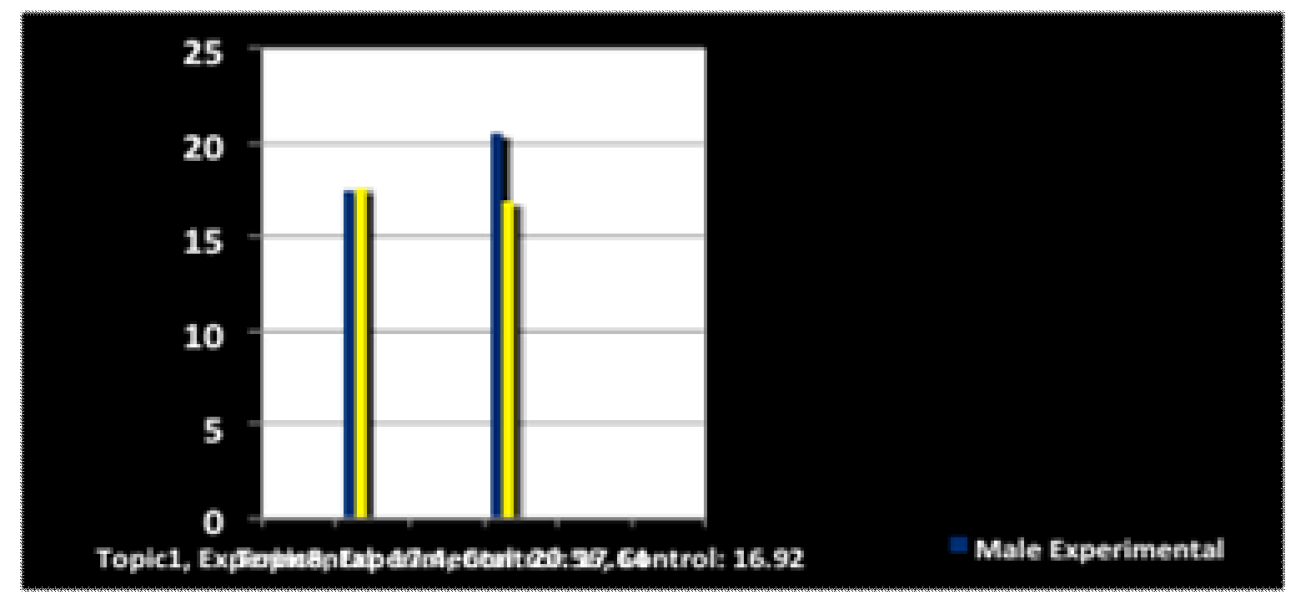

Graph: 2

Mean Scores of Pre-Test and Post-Test in both Groups 
Table: 6

Independent Samples Test of Experimental and Control groups

\begin{tabular}{|c|c|c|c|c|c|c|c|c|c|c|}
\hline & \multicolumn{3}{|c|}{ 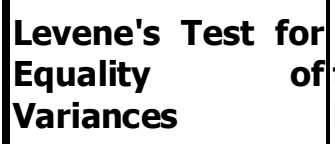 } & \multicolumn{4}{|c|}{$\begin{array}{l}\text { t-test for } \\
\text { Equality of Means }\end{array}$} & & \\
\hline & & \multirow[b]{2}{*}{$\mathbf{F}$} & \multirow[b]{2}{*}{ Sig. } & \multirow[b]{2}{*}{$\mathbf{T}$} & \multirow[b]{2}{*}{ Df } & \multirow{2}{*}{$\begin{array}{l}\text { Sig. } \\
(2- \\
\text { tailed })\end{array}$} & \multirow{2}{*}{\begin{tabular}{|l} 
Mean \\
Difference
\end{tabular}} & \multirow{2}{*}{$\begin{array}{l}\text { Std. Error } \\
\text { Difference }\end{array}$} & \multicolumn{2}{|c|}{$\begin{array}{l}95 \% \text { Confidence } \\
\text { Interval of the } \\
\text { Difference }\end{array}$} \\
\hline & & & & & & & & & Lower & Upper \\
\hline $\begin{array}{l}\text { Topic } 1 \\
\text { PreTest }\end{array}$ & $\begin{array}{l}\text { Equal } \\
\text { variances } \\
\text { assumed } \\
\text { Equal } \\
\text { variances } \\
\text { not assumed }\end{array}$ & 1.081 & .304 & $\begin{array}{l}-.577 \\
-.577\end{array}$ & $\begin{array}{l}48 \\
46.852\end{array}$ & $\begin{array}{l}.567 \\
.567\end{array}$ & $\begin{array}{l}-.240 \\
-.240\end{array}$ & $\begin{array}{l}.416 \\
.416\end{array}$ & $\begin{array}{l}-1.076 \\
-1.077\end{array}$ & $\begin{array}{l}.596 \\
.597\end{array}$ \\
\hline Topic 2 & $\begin{array}{l}\text { Equal } \\
\text { variances } \\
\text { assumed } \\
\text { Equal } \\
\text { variances } \\
\text { not assumed }\end{array}$ & 2.596 & .114 & $\begin{array}{l}13.748 \\
13.748\end{array}$ & 46.356 & .000 & $\begin{array}{l}6.240 \\
6.240\end{array}$ & $\begin{array}{l}.454 \\
.454\end{array}$ & $\begin{array}{l}5.327 \\
5.327\end{array}$ & $\begin{array}{l}7.153 \\
7.153\end{array}$ \\
\hline Topic 3 & $\begin{array}{l}\text { Equal } \\
\text { variances } \\
\text { assumed } \\
\text { Equal } \\
\text { variances } \\
\text { not assumed }\end{array}$ & .736 & .395 & 16.550 & 46.879 & .000 & 6.520 & $\begin{array}{l}.394 \\
.394\end{array}$ & 5.728 & 7.312 \\
\hline Topic 4 & $\begin{array}{l}\text { Equal } \\
\text { variances } \\
\text { assumed } \\
\text { Equal } \\
\text { variances } \\
\text { not assumed }\end{array}$ & .883 & .352 & 14.903 & 47.336 & .000 & 6.480 & .435 & 5.606 & 7.354 \\
\hline Topic 5 & $\begin{array}{l}\text { Equal } \\
\text { variances } \\
\text { assumed } \\
\text { Equal } \\
\text { variances } \\
\text { not assumed }\end{array}$ & .172 & .681 & 11.145 & 47.967 & .000 & 5.320 & .477 & 4.360 & $\begin{array}{l}6.280 \\
6.280\end{array}$ \\
\hline
\end{tabular}




\begin{tabular}{|c|c|c|c|c|c|c|c|c|c|c|}
\hline Topic 6 & $\begin{array}{l}\text { Equal } \\
\text { variances } \\
\text { assumed } \\
\text { Equal } \\
\text { variances } \\
\text { not assumed }\end{array}$ & 4.184 & .046 & $\begin{array}{l}14.870 \\
14.870\end{array}$ & 43.094 & $\begin{array}{l}.000 \\
.000\end{array}$ & $\begin{array}{l}5.80000 \\
5.80000\end{array}$ & $\begin{array}{l}.39004 \\
.39004\end{array}$ & $\begin{array}{l}5.01577 \\
5.01345\end{array}$ & 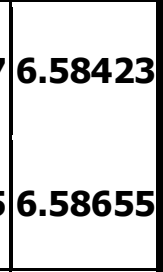 \\
\hline Topic 7 & $\begin{array}{l}\text { Equal } \\
\text { variances } \\
\text { assumed } \\
\text { Equal } \\
\text { variances } \\
\text { not assumed } \\
\end{array}$ & 2.560 & .116 & $\begin{array}{l}14.453 \\
14.453\end{array}$ & 42.584 & $\begin{array}{l}.000 \\
.000\end{array}$ & 6.56000 & $\begin{array}{l}.45387 \\
.45387\end{array}$ & $\begin{array}{l}5.64743 \\
5.64442\end{array}$ & $\begin{array}{l}7.47257 \\
7.47558\end{array}$ \\
\hline \begin{tabular}{|l} 
Topic 8 \\
PostTest \\
\end{tabular} & $\begin{array}{l}\text { Equal } \\
\text { variances } \\
\text { assumed } \\
\text { Equal } \\
\text { variances } \\
\text { not assumed }\end{array}$ & .072 & .790 & 8.278 & $\begin{array}{l}48 \\
47.934\end{array}$ & $\begin{array}{l}.000 \\
.000\end{array}$ & $\begin{array}{l}3.64000 \\
3.64000\end{array}$ & $\begin{array}{l}.43970 \\
.43970\end{array}$ & $\begin{array}{l}2.75593 \\
2.75590\end{array}$ & $\begin{array}{l}4.52407 \\
4.52410\end{array}$ \\
\hline
\end{tabular}

It was found that, in the case of topic1, the obtained $p$ value was higher than $0.05(P=0.567)$. As illustrated in Table 6, it can be concluded that there were no significant differences between the mean scores of the experimental and control groups in writing the first topic. This is to say, both groups were homogenous in terms of their knowledge of writing skill prior to the present study.

As demonstrated in the previous table the $t$-test results show that there is a meaningful difference between the means of the two groups in topics $2,3,4,5,6,7$, and 8 .

It also indicates that in topics $2,3,4,5,6,7$, and 8 since $P$ value is lower than the alpha level of $0.05(P=.000)$, there was a significant difference between the experimental and control male groups in their knowledge of writing topics. Here again, based on this finding, we could reject the researcher's null hypothesis (Providing background Information via e-mail by the teacher and writing e-mail by the students does not have any effect on Iranian EFL learners' writing ability) in that there is a significant difference between the writing performance of male students who write e-mail, via receiving background information, and those male students who write traditionally without receiving background information.

\section{DISCUSSION}

In this paper, providing background Information via e-mail by the teacher and writing e-mail by the students proved effective in increasing Iranian EFL learners' writing ability. Finally, providing background Information via e-mail by the teacher and writing e-mail by the students in experimental male learners showed statistically significant results compared to control male learners in terms of the learners' writing ability. 
In conclusion, it is noteworthy to reiterate the fact that due to the scarcity of the research and lack of sufficient evidence in this burgeoning field, more research is merited to gain deeper insight into the best and most effective ways to practice and integrate technology into language learning and teaching environments.

The main goal of this study was to find the effects of technology on learners' writing ability. It was supposed that, the use of writing e-mails would help learners in achieving a higher writing skill. The study showed that there was a significant difference between those who worked with technology from those who did not work with technology and took part in traditional classes.

The results of this study are to some extent similar to those obtained by Toyoda (2001) who claimed that "the technology can have a positive impact on learner autonomy when learners have extensive experience with technology" (Toyoda 2001, p. 11). He furthered that "it also can have a positive impact on autonomy only when learners perceive technology as a useful tool" (Toyoda 2001, p. 11).

The positive effects of technology on language learning also have been demonstrated by Warschauer (1996) who found that using technology in teaching encourages learners to develop their language skills.

The common things among all these studies is that, by connecting classroom learning with other learning outside the class situation students may see new ways of learning experience as an extension to the future (Allford Pachler 2007).

In other research findings, Donaldson and Kötter (1999) and Kartal (2002) found that CALL applications are interesting and motivate students in foreign language learning.

Different justifications can be brought for this finding. First of all, the participants of this study were advanced students and in lower levels there may be some differences. Advanced students may have the experience of working with computers for some years and their writing ability might have improved to some extent because of dealing with the language before. It seems that for them, the use of technology influences their writing ability.

\section{CONCLUSION}

The findings of the present study support the efficacy of providing background Information via email by the teacher and writing e-mail by the students in experimental group showing significant improvement over the control group who did not receive background information via e-mail. CALL framework proposed in the study attaches ultimate importance to the whole process of learning, writing. In this study, the experimental group who received background information proved successful in writing.

The present study has really got some valuable results and surely can provide some enlightenment to EFL learning in Iran. But there are still some uncertainties and limitations needing further research. 
In order to answer the main question of the study, namely' Does providing background Information via e-mail by the teacher and writing e-mail by the students have any effect on Iranian EFL learners' writing ability?' we had to compare the mean scores of experimental and control groups. As previous tables showed, there was a wide gap in their scores, indicating the superiority of experimental group to control group in terms of their performance on writing topics.

\section{Pedagogical Implications for Teachers \\ With respect to providing EFL learners background information, it is suggested that teachers activate related knowledge of the students to low level learners, too. It can be argued that learners at lower levels might not have enough proficiency to write, but it would be possible by providing support on the part of the instructors. It is also suggested that providing EFL learners' background information be used with different proficiency level learners.}

Thus, providing EFL learners' background information can be taken into account as being effective when dealing with different level learners. Generally speaking, Iranian EFL learners are mostly inclined to look up to their teachers to provide them with correct writing rather than by themselves. Another suggestion is that when activating background information teachers should make use of different ways of activating background information.

\section{For Learners}

The implication is that learners can benefit a lot from this kind of instruction and that teacher intervention can be very instrumental in the process of teaching writing. Regarding online courses and e-learning in general, it is suggested that the students improve their language proficiency on line through fun, i.e., chatting with their friends and classmates in the foreign language, English.

\section{For Researchers}

Although this study firmly supported the positive role of activating background information intervention via e-mail in writing development, we see a need for further studies to be commissioned not only in the area of writing, but in all other language skills, with learners of different ages and proficiency levels, to better reveal the relative share of activating background information via e-mail in accomplishment of the most important concern in education, i.e. the learning. On the other hand, it would be a good idea to conduct further research with female participants.

It is highly recommended for those who are willing to do researches in the domain of activating background information to study its effect in other levels of language proficiency and scrutinize its role in other skills as reading. Iranian Researches can also do some researches at other institutes apart from Iran Language Institute and other cities rather than Tehran and researcher from other countries can do the same with the learners of different nationalities to zoom the effect of first language, if any, on the results of the studies.

\section{For Test Designers}

It is also believed that the findings of the present study can contribute to the improvement of testing and online courses as well. It is suggested that test makers evaluate learners on the basis of their overt incompetency regarding their on line performance. It is also recommended that more 
ways of activating background information should be provided for learners with low proficiency levels. On the other hand, some key words as ways of providing background information activation might seem appropriate for learners with higher proficiency levels as they might possess deeperlevel processing capabilities than lower level learners. Additionally, while dealing with low level learners, test makers are advised to test one structure in their writing performances at a time and avoid the combination of certain structures as it may result in learners' confusion and uncertainty.

\section{SUGGESTIONS AND RECOMMENDATIONS FOR FURTHER RESEARCH AND SUMMARY}

Suggestions and recommendations for future research are as following.

$>$ The sample size in this study was relatively small $(N=50)$. However, further research with larger samples may provide different results.

$>$ The proficiency level of the participants in this study was advanced. Further research with learners of different proficiency level may provide different results.

$>$ In this research male learners participated, so conducting more research with female participants may bring about different results.

$>$ This study was conducted within a period of four weeks during which eight writing topics were introduced. It is conjectured that longer treatment with more writing topics may result in different outcomes.

$>$ Since the maximum of $\mathbf{3 5 0}$ words per writing was set as the limit in this study, it is suggested that further research be done with different range of words, preferably 150 w0rds.

$>$ Context is one of the most important factors influencing the results. Therefore, it is suggested that using different contexts may produce different results.

$>$ Finally, more research is merited utilizing different types of activating background information than those of the present study through technology.

This study revealed that activating background information via e-mail by the teacher and writing e-mail by the students is effective in enabling

learners to improve their writing skill. In accordance with and in support of previous research, the results of the present study indicated that the learners who received background information via e-mail by the teacher improved their writing skill. Those who did not received background information did not make progress in their writing skill.

Finally, it is hoped that the findings of this study provide further directions and guidelines for researchers and those interested in writing skill and background knowledge with the aim of enhancing learning and supporting the needs and requirements of learners.

It is also hoped that by integration of activating background information and writing skill more opportunities are provided for all to equally benefit from learning and education. 


\section{BIODATA and CONTACT ADDRESSES of the AUTHORS}

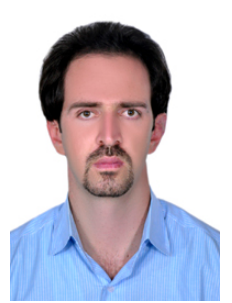

Behzad NAZARI has an M.A. in TEFL from IAU South Tehran Branch. He is interested in Assessment, Dynamic Assessment, Testing, sociolinguistics, and related fields. He has been teaching English as a foreign language in Iran for four years and he is an English teacher at the ILI.

Behzad NAZARI (Corresponding Main Author)

MA of TEFL, Islamic Azad University, South Tehran Branch, Tehran, IRAN

English Instructor at Iran Language Institute

behzad.nazari1362@yahoo.com

Address: Iran Language Institute, Rasht St., Valiaasr St., Tehran, IRAN

Zip Code: 1591719811

Telephone Number: 09356816340

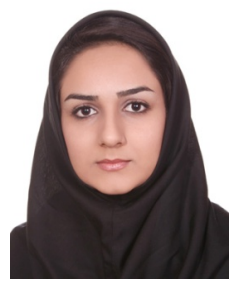

Sahar NIKNEJAD has an M.A. in TEFL from IAU South Tehran Branch. She is interested in Assessment, Teaching theories, and related fields. She has been teaching English as a foreign language in Iran.

Sahar NIKNEJAD (Co-Author)

MA of TEFL, Islamic Azad University,

South Tehran Branch, Tehran, IRAN

No. 10, Shahid Salehi Alley, Dampezeshki St.,

21 Metri-e Jay St., Ostad Moein Station, Tehran,

Zip Code: 1349745377IRAN.

Phone: 00989356816340

Email: sahar.niknejad@yahoo.com

\section{REFERENCES}

Allford, D. \& Pachler, N. (2007). Language, autonomy and the new learning environments.

Frankfurt am. Main: Peter Lang Publishing.

Calico (2001). Bilgisayar Destekli Dil Ögreniminde Bilimsel Çalısmalar: Gelistirme, Egitbilimsel Yenilikler ve Arastırma [Online]. http://calico.org/CALL document-Turkish.pdf retrived on1 March 2013.

Dhaif, H. A.(1989).Can computers teach languages? English teaching forum.27(3),pp.17-19.

Donaldson, R. P. ve Kötter, M. (1999). Language learning in cyberspace: Teleporting the classroom into the target culture. CALICO Journal, 16 (4): 531-558. 
Gonglewski, M., Meloni. C. and Brant, J. (2001). Using E-mail in Foreign Language Teaching: Rationale and Suggestions. The Internet TESL Journal, 7 (3), March 2001.

http://iteslj.org/Techniques/Meloni-Email.html

Hardisty D. \& Windeatt S. (1989) CALL, Oxford: Oxford University Press.

Jones, J. (1998). Getting Started: Introducing CALL to TESOL Students. In Proceedings of the 1998 World CALL Conference. Melbourne: University of Melbourne.

Jones, J. F. (2001). CALL and the Responsibilities of Teachers and Administrators. ELT Journal, 55 (4), 2001.

Jones, C. \& Fortescue, S. (1987). Using computers in the language classroom. New York: Longman.

Kartal, B. (2002). Açıkögretim ögrencilerinin yabancı dil derslerinde basarı düzeylerini arttırmaya yönelik web destekli hizmetler. Açık ve Uzaktan Egitim Sempozyumu. Eskisehir, Turkey (23-25 May 2002) http://aof20.anadolu.edu.tr retrieved on 10 April 2013.

McCarthy, B. (1999). Integration: the sine qua non of CALL. In CALL-EJ Online, Vol. 1, No. 2, September 1999.

Mei Lin Ho, C. (2000). Developing Intercultural Awareness and Writing Skills through Email Exchange. The Internet TESL Journal, 6 (12), December 2000. http://iteslj.org/Articles/HoEmail.html

Suler, J. (n.d.) The basic features of E-mail Communication. Selfhelp Magazine. http://selfhelpmagazine.com/articles/internet/features.html Retrieved May 2005.

Toyoda, E. (2001). Exercise of Learner Autonomy in Project-Oriented CALL. CALL-EJ. 2001, 2(2).

Warschauer, M. (1996). Computer-assisted language learning: an introduction. In: S. Fotos (ed.) Multimedia language teaching. Tokyo: Logos International. pp. 3-20. 